\title{
Character Building or The Development of the Personality: An Innovative Methodological Platform in the Informational Educational Space
}

\begin{abstract}
Currently an acute crisis exists regarding the traditional methodological platform of the higher education system. Research continues with studies of individual facets of human personality without referring to new methodological realities. The dominant model of the University has remained unchanged for about 200 years. Today, however, the goals, means and agents of socialization are changing. In this essay, a new methodological platform for personality development is proposed and discussed, one which examines the role of behavioral stereotypes in the social and professional success of the individual.

Keywords: network paradigm for personality development, mental activity, behavior, activities, stereotypes of mental activity.

概要 (Mikhail N. Berulava \& Galina A. Berulava: 性格塑造或个性发展: 在信息教育领域的一项创新性的 方法论的平台): 近来, 传统的高等教育体系的方法论平台存在着较为严重的危机。持续进行䏌于人 类个性方面的一些研究, 然而却不涉及新的方法论的现实。大学的主导模式大约已经有 200 年保持 不变。但是, 今天, 社会化的目标, 手段以及代理人均在发生着变化。在这篇文章中, 提出并讨论 了一种新的个性发展的方法论平台, 其中探讨了行为定型在社会和个人职业成功中所起到的作用。

关键词: 个性发展的网络范式, 心理活动, 行为, 活动, 心理活动的定型
\end{abstract}

Abstract (Mikhail N. Berulava \& Galina A. Berulava: Charakterbildung oder die Entwicklung der Persönlichkeit: Eine innovative methodologische Plattform im informativen Bildungsraum): Gegenwärtig besteht eine akute Krise hinsichtlich der traditionellen methodologischen Plattform des Hochschulsystems. Die Forschung befasst sich weiterhin mit der Erforschung einzelner Facetten der menschlichen Persönlichkeit, ohne sich auf neue methodische Realitäten zu beziehen. Das dominierende Modell der Universität ist seit rund 200 Jahren unverändert. Heute jedoch verändern sich die Ziele, Mittel und Akteure der Sozialisation. In dem vorliegenden Artikel wird eine neue methodologische Plattform zur Persönlichkeitsentwicklung vorgeschlagen und diskutiert, die die Rolle von Verhaltensstereotypen für den sozialen und beruflichen Erfolg des Individuums untersucht.

Schlüsselwörter: Netzwerk-Paradigma für Persönlichkeitsentwicklung, mentale Aktivität, Verhalten, Aktivitäten, Stereotypen der mentalen Aktivität

Резюме (Михаил Николаевич Берулава и Галина Алексеевна Берулава: Формирование характера или развитие личности: Инновационная методологическая платформа в информативном образовательном пространстве): В настоящее время присутствует острый кризис в отношении традиционной методологической платформы системы высшего образования. Исследование продолжает заниматься отдельными гранями человеческой личности, не опираясь на новые методические реальности. Доминирующая модель университета примерно 200 лет остается неизменной. Однако сегодня изменяются цели, средства и действующие лица социализации. В настоящей статье предлагается и рассматривается новая методологическая платформа для развития личности, которая исследует роль стереотипов поведения для социального и профессионального успеха индивидуума. 
Ключевые слова: сетевая парадигма для развития личности, ментальная активность, поведение, действия, стереотипы ментальной активности

$$
* * *
$$

The educational system of the 21st century needs new methodological bases and innovative educational technologies that provide compliance with the realities of the emergent information society. Given the multifaceted influences of electronic information sources, changes in the personal, behavioral, and cognitive development of today's youth require a fundamentally different approach to content and teaching technologies, and, consequently, to the development of new criteria for quality assessment of the growth and development of students in schools and in higher education.

The practice of teaching is informed and determined by those theoretical constructs on which it is based. Thus, on their long and intertwined journeys, theories of psychology and pedagogy have focused their attention on teaching practice, each offering certain advantages. There remains the fascination of psychoanalysis from the world of psychology in spite of the fact that its theoreti$\mathrm{cal} /$ experimental/empirical base is a matter of concern. But at the same time, its heuristic achievement lies in drawing attention to the role of the unconscious in human life (Fadiman, 1996). More recently, cognitive psychology has demonstrated the role of mindfulness, particularly regarding the development of mentality and personality (G. Berulava, 2010a). The work of such important contributors as Jerome Bruner (1996) and Lev Vygotsky (1965), who have demonstrated the role of culturally-derived language, perception, problem solving, and creativity, offers much improvement to both the purpose and potential of teaching and learning. Humanistic psychology, with its challenge to both behaviorism and Freudian psychology, particularly through the work of Carl Rogers (1942) and Abraham Maslow (1943), has identified the fundamental need of the individual's drive toward self-actualization and the importance of safe, trustful environments. Each of these, has made possible a greater understanding of the potential of learners' psychological resources. The aggregated achievements largely do not exclude, but mutually complement each other.

To a considerable extent, each of these developed distinctively in different national and cultural settings. And in the former USSR, Marxist-Leninist ideology generated a number of its own theoretical constructs, particularly with emphasis on the collective as opposed to the Western emphasis on the individual (Zimmerman, 2011). Lev Vygotsky's socio-historical approach with its focus on shaping of the individual from the "outside in" has in recent years received much acclaim in western societies (Vygotsky, 1965).

Twentieth Century psychologies and pedagogics clearly demonstrate the dominance in various national sciences of action theory (Fadiman, 1996) as the result of the implementation of the postulates of these ideologies. The importance of action theory (Parsons, 1937, 1968) with its systemtheoretical approach in the co-development of the individual and society cannot be denied. At the same time, every theory has its range of application and implementation within its cultural/historical context and may not enjoy universal domination over long periods of societal development. Each of the aforementioned psychologies is, in fact, a product of the industrial age. While this does not necessarily render them obsolete, each lacks a systemic structure suited to an information-dominated society. Today's milieu suggests the need for a new paradigm of human development suited to a view of the realities of the information age.

Current appeals to the sphere of rational consciousness are and have been embodied in the dominance of the verbal-monological form of teaching, to organizing training from the general to the specific, from theory to practice, from knowledge to skills. However, it is clear that many young people today have a completely different style of thinking, appealing, at least intuitively, to other cognitive strategies (G. Berulava, 2010b). It seems that the existing verbal and theoretical constructs are in fact in conflict with behavioral, communicative, and cognitive commonplaces that were more sustainable in times past. 
Today, the result of the dominance of action theory, as exemplified by the contention that knowledge is constituted in action or performance in academic knowledge and skills, in national education systems can be seen in the fact that you will not see a single section devoted to behavior or to the unconscious in many Russian psychology textbooks (G. Berulava, 2008). However, it is easy to overlook the fact that it is mostly everyday behaviors and their cumulative effects which determine the civility and mentality of a nation and its culture, and which contribute greatly to an individual's success in life.

Very often the visible form of a person's learned mental activity refers to behavior. This is, however, an overly simplistic, unproductive and non-heuristic description. Let us understand behavior in this context as the type of mental activity that is not conscious at the stage of its implementation, although it may be analyzed purposefully in the future. In this sense behavior refers to automaticity, a term used by the psychologist Benjamin Bloom (1986) to describe unthinking, automatic behaviors, for example, tying one's shoe laces. In contrast to behavior, purposeful action is mental activity that is determined by a conscious objective. Human activity in this latter sense represents conscious, rational, purposeful action.

Behavioral patterns are much more stable than the rational forms of activity in that they "form a habit and harvest a nature." But today the higher level of personality development remains outside the sphere of the Russian education system. Unfortunately, this is the case not only in theoretical psychology and pedagogy, but also in national educational practice, behavioral psychology moved into the background, refusing to respond to Marxist ideology with its dominant activity approach. And, in our opinion, this is quite unjust. It is not rational and thoughtful activities which are more often found in daily life, but rather unconscious automated patterns of behavior. Communicative stereotypes are also very important in our lives, when a person is communicating in standard situations using established and familiar patterns, not thinking consciously about what to say and how to respond. He or she does it using familiar phrases and clichés. Each person uses emotional stereotypes in interpersonal communication, expressing emotions, likes and dislikes in a familiar way.

Indeed, a civil person, whose effective behavior patterns have been formed, does not have to reflect whether to give up a bus seat to an elderly person or a small child. Such an individual does this automatically. It may seem a small gesture, but such activity has cumulative effects in the building of a civil society.

Appropriate civil behavior patterns are best established early on. An individual need not ponder whether to help an elderly person cross the road, to help someone who drops something, to speak politely. All this should come automatically. These should be automatic responses.

The positive stereotypes in the sphere of personal emotional activity are also very important, for example smiling without reflecting when welcoming another person. Such responses are the so$\mathrm{cial} /$ moral fabric of a civil society.

It is a societal deficit when young people do not understand that a cultured, civilized person should be able to express joy when someone feels good or succeeds. Knowing how to speak to others politely, how to make calls to services, how to talk to supervisors and other such everyday responses are reminders that manners are fundamental to civil society. The hopeful thing is that civil behavior can be taught and learned, especially when it is modelled by teachers and others in authority. An old saying tells us that civil behavior is better caught than taught.

It is abundantly clear that in Russia the school as an institution has not taken up this task in any serious manner. Undoubtedly, pupils were and are told that they should behave well. But nobody seems to know exactly what 'well' means and in what situations this should happen (sadly, even 
teachers are not always an example of proper behavior). Today, the schools and universities continue to attempt to improve academic standards, but elements of civil behavior are not included in the new educational standards (G. Berulava, 2010b). This ought to be no less an important concern than fostering the development of a rational consciousness, the development of the mind and supporting the acquisition of knowledge and skills. John Dewey (1907) went so far as to say that the school has two important missions: academic and social, but that the social mission, that is, the mission of building up an active, civil, participatory society is the more significant of the two.

Often, this consideration is missing in school and university education and in published educational programs and standards. It is impossible to develop a full personality and a healthy society by shaping consciousness only and not shaping behavior. Certainly, both must be taken seriously, and they have different but complementary psychological manifestations.

The concept of disciplined practice was standard procedure in the Russian pre-revolutionary school (Berulava, 2001). In the Soviet era, this concept was always viewed with a negative connotation, and it has remained so till the present day (Berulava, 2001). Of course, drill and practice, also known as repetitive disciplined practice, is not of itself a sufficient condition of education, but it is significant and should not be underestimated. Anyone who has succeeded at higher, expert levels knows well the value of disciplined practice, whether in music, science, the arts, reading, even in sports.

An example of such a curriculum is found at the Suvorov military school of Moscow where positive social/moral habits are learned early on to the degree that they become automatic. Parents who send their children there are subconsciously aware of the proverbial saying, "they will be taught how to live there." They are confident that patterns of productive mental activity will be formed at the behavioral, communicative, affective, and physical levels. It is a commonplace to speak of 'habits' in everyday life. Habits are indeed habitual, that is, people act on them without thinking. The pupils are expected to rise early, dress quickly, tidy their clothes and make their beds. These are simple, natural habits of personal everyday hygiene. They are taught that it is necessary to communicate with elderly people and to treat others with respect. They are expected to form the habit of systematic reading and other important stereotypes of mental activity (M. Berulava \& G. Berulava, 2009). In the laboratory school of John Dewey at the University of Chicago in the late $19^{\text {th }}$ and early $20^{\text {th }}$ centuries, students were expected to clean the school rooms, to help with food preparation, to work with others on projects, and to learn habits of civil behavior. Dewey wrote that "we cannot overlook the factors of development of character building involved in the training in habits of order." (1907, p. 3) So, this is not a new idea, but one we can learn from and rediscover.

Many wealthy people in Russia send their children to private schools, where there is a very strict and often ascetic regime (G. Berulava, 2010b). They are attracted to such schools not only because they feel a positive potential will be formed in their children, but because the child will be taught in "strict frames," the meaning of which is the will to establish certain behavioral patterns in their children, for instance, the habit of valuing work and self-regulation. Further, they learn to dance, sing, and participate in the arts and sports programs in such schools because school life is about community as well as academics.

Sadly, it will come as no surprise that large numbers of young people who complete school and seek work lack the most basic communication and team-work skills. Nowadays, such terms "communication format" and "team-building" are increasingly used. These are social skills, sometimes called "soft skills" that carry over into widely different spheres of human endeavors and relationships (M. Berulava \& G. Berulava, 2009). But what are we to think when young people graduate from school and university with a deficient and narrow range of communicative behavioral patterns and habits? The necessary abilities to communicate are primarily determined by the presence of adequate and 
productive communication and emotional experiences, taught and learned in civil conditions which prepare young people for success in domestic life, society, and in careers.

Cognitive growth and development plays an equally important role in human life. In most cases we at first do not see and then define, we first define for ourselves a certain phenomenon, and then observe it. In all the chaos of the outside world, we have an obvious tendency to perceive information in the form of stereotypes, that is, to include this information automatically in a certain system of coordinates. These are established in relation to typical situations in human life, and they then become unconsciously active in these standard situations.

Cognitive growth as seen from certain views of Gestalt psychology (Bruner, 1996) in time enjoys a certain priority over the further development of behavioral, communicative and affective stereotypes which will function as the actual, real-time forms of an individual's mental activities.

Thus, most human behavior in everyday practical situations is automatic and manifested in behavioral acts, communication and emotional response. In practical situations cognitive fixed images are actualized automatically. This does not mean that individuals will act only on that basis, since these actions can be accompanied by some analytic-synthetic reflection in the future. Cognitive images are stable, mindful algorithms, primarily based on implicit knowledge, in which the strategies of problem solving are presented a priori (James, 1914; 1996).

Thus, fixed mental images play an enormous role in human life. Any changes of them are seen as an attack on the foundations of our world.

We have already noted that the imitation of external repetitive patterns of behavior and how their internalization is a very important mechanism for the formation of positive behavioral stereotypes. In the past, mass media played a very important positive role in this regard. Our best film-makers, actors and, in general, whole generations have grown older under the influence of the positive examples of national cinema. As the psychologist Albert Bandura has noted, we do what we see (Bandura, 1986).

In the age of information technology, ever-emerging forms of mass media play an important role, presenting humanistic patterns of behavior which are then internalized. It is one of the most essential and effective mechanisms for shaping human behavior. In earlier times cultural stereotypes of behavior, along with the transmission of certain cultural values, were passed on from generation to generation.

Unfortunately, modern television, film, internet, and social media have ceased to be sources of positive and productive patterns of behavior; on the contrary, persistently, they often promote patterns of pathological, aggressive, anti-human, inappropriate behavior (G. Berulava, 2010a).

It is impossible today to underestimate the immense role of the internet in the formation of stereotyped patterns in a person's mental activity. Psychologically speaking, the internet to a great extent replaces real activity with virtual activity; it is now credited by young people with the ability to establish oneself in life through activity in the virtual world (G. Berulava, 2010a).

The current education system fails to take into account that the implementation of new information technologies has created a global transformation, completely replacing former systems of knowledge acquisition. The lack of hierarchy in the information, as opposed to knowledge, that is purveyed is a characteristic of "network education," and the logic of perception and internalization of such information is determined primarily by the motivation of the learner, mediated by his or her "what-is-the-purpose-in-my-life?" orientations.

The virtual sphere of communication and reception of information forms novel patterns of mental activity, considerably different from those formed in traditional educational spaces. It is worth pointing out that information networks are far more than a technical tool, having acquired the sta- 
tus of a new culture with its own semi-sphere. Texts and images presented by electronic carriers of information today act as sensory and perceptual standards that greatly change the framework of norms of behavior and social interaction.

Virtual space has turned into a new reality which replaces the real world of things, people and relationships for many young people. The analysis of human life in virtual space gives reason to talk about and thoughtfully examine previously unknown processes that affect the perception of people and their mental functioning. Replacing objective reality with virtual reality has become for many people a way of life. In this sense, technologies have gotten ahead of the existing infrastructures of human relationships and have begun to create unknown consequences (G. Berulava, 2008).

It seems utterly reasonable to underline the crucial role which school and university could and must play in the formation of productive behavioral patterns. They emerge first in the family setting, as imitation and reaction, and then as patterns of behavior stimulated by parents. However, in systematically organized education they must be formed in a like manner as an imitation of the behavior of teachers, but mainly as the result of systematic, purposeful experiences in humane behavior in situations created by those we entrust in school settings to guide the young. There is much to criticize regarding the old system of Soviet education, but for better or worse that system offered young people patterns of moral behavior that were successfully internalized and manifested in society (G. Berulava, 2008).

We suggest that applications of psychological principles by those working in school and university settings in the process of special behavioral training could rectify this gap substantially. If a person speaks certain necessary words 100 times and smiles in the course of typical training situations, these reactions will remain in his or her unconscious, "in autopilot mode", and he or she will utter them completely freely and correctly at the moment they need to be expressed (G. Berulava, 2010b). That determines the choice of words to express, for example, delight, surprise or contempt. So much of the career and destiny of the young person greatly depends on these seemingly simple things.

A special training system could achieve that goal, primarily through the work of psychologists and educators, who can create these typical communication situations and work out the necessary communication patterns for schoolchildren and older students in the making of civil society. Yet the behavioral trend in the activities of psychologists has recently receded into the background. In fact, training work today is based on the creation of completely atypical and artificial situations, possibly appealing and entertaining, as a form of emotional self-expression, to search for associations and other artificial constructions of life patterns among young people (M. Berulava \& G. Berulava, 2009). In many cases, the interaction of psychologists with trainees turns into an adapted presentation of a psychology course, based on a verbal-monological style of material delivery. But a great need exists for practical applications centering on daily life where students are engaged in the purposeful and systematic formation of effective, socially positive patterns of behavior.

Thus, the education system ignores a very important layer of human expression that can manifest itself not only in the sphere of purposeful activity, but also in the sphere of unconscious behavior, often of a stereotyped nature. However, reliance only on an appeal to the sphere of theoretical consciousness, with the support of verbal-monological methods, corresponding to this teaching approach, has resulted in today's situation, where schooling provides the world with culture-deficient, non-adaptive, aggressive, intolerant personalities showing inadequate forms of behavior.

What is the theoretical basis of network education that we have developed, which, from our point of view, should be the new methodological platform for the present education system? Its basic postulate is personality development with the support of the rational consciousness sphere combined with the sphere of the unconscious. This implies the need to form not only a sphere of 
knowledge, skills and abilities, to establish mechanisms of thinking, to awaken individual creative potential in the process of rational purposeful activity, but also to educate young people in positive and productive behavioral, communicative, affective and motor stereotypes of mental activity (M. Berulava \& G. Berulava, 2009).

The human psyche is indisputably considerably active not only with regard to the sphere of the rational, but also to the sphere of the unconscious. The unconscious, as Vygotsky notes, "is not separated from the consciousness by some impenetrable wall - the processes that start there often have their continuation in consciousness and, conversely, a number of conscious issues are supplanted into the subconscious sphere. There is a constant, dynamic connection between the two spheres: the unconscious influences our actions, is revealed in our behavior, and by these tracks and manifestations we learn to recognize the unconscious and the laws that govern it" (Vygotsky, 1965, p. 94). The latter sphere produces all kinds of stereotypes of mental activity embodied by the stereotypes of behavior, communication, emotional response and motor activity. However, many people appear not to have the skills necessary to deal in socially positive ways with the problems of everyday life, or have acquired the wrong skills and erroneous patterns of behavior. Some people do not know how to be welcoming and friendly, how to talk in company, how to express an argument or point of view appropriately, how to reject unreasonable requests, or how to express a range of simple positive behaviors that are the essence and fabric of civil society. (Hjell \& Ziegler, 1997).

Specialists have always stressed the importance of automatic, stereotyped behavior in humans as predominant, since in many cases it is the most appropriate, and in other cases it is simply necessary (Bodenhausen \& Lichtenstein, 1987). The famous British philosopher A.N. Whitehead (1999) argued that civilization moves forward by increasing the number of operations that we can carry out without thinking about them. William James $(1888,1914)$ also insisted that "ninety-nine hundredths and, perhaps, ninety-nine thousandths of our operations are completely automatic and customary, from getting up in the morning to going to bed in the evening. Dressing and undressing, eating and drinking, greeting and parting: most of the forms of our ordinary speech are so stereotyped by repetition that they can almost be called reflexes. For each kind of experience, we have an automatic, pre-prepared reaction...."

As James notes, we are creatures of habit, stereotyped individuals, imitators and copies of ourselves in the past. And since under any conditions this is what we are inclined to, it follows that the fundamental concern of a teacher should be to foster in learners at any level a set of habits that will serve them well in life. Education creates behavior, and habit is the material from which the behavior is made. There is no unhappier a creature than a man or woman in whom there is nothing customary, except indecision. For such an unfortunate person, raising a cup to the mouth, getting up and going to bed, the beginning of any fragment of work becomes a matter of explicit volitional decision. Much of our time, decisions to do or refuse to do, are things firmly rooted in automaticity, so as not to occupy consciousness at all (M. Berulava \& G. Berulava, 2009).

In our theory of networked education, stereotypes are a form of mental activity determined by the sphere of the unconscious and actualized in the process of solving typical problems. That is, we are talking about stereotyped behavior in which a certain attitude is stable for the behavior of a particular person within the framework of the occurrence of typical problems in life. The concept of stereotypes is based on the concept of behavior in the broad sense of the word. Unlike activity as we have described it, behavior is not subordinated to a previously set goal: there is no preliminary thinking, plan of action nor foresight; it is mediated by the sphere of the unconscious and is therefore automatic.

Typically, researchers, as a rule, do not focus on differentiation between the rational and unconscious components of the subject's mental activity, do not take into account that the subject very 
often forms relationships with people based on unconscious stereotypes of behavior that he or she has developed. Behavior in this case is viewed as the level of mental activity initially not controlled by consciousness. In the broad sense of the word, behavior includes both uncontrolled acts of communicative and affective behavior, as well as behavior in the narrow sense of the word, as a set of defined behavioral acts. As we define the matter, differences between the concepts of activity and behavior are explicit. The distinctive features of activity are its awareness, purposefulness, objectivity and instrumentality. The awareness of activity means its thoughtfulness, planning and anticipation of result, the existence of a certain logical scheme. Alongside that conception, there is a point of view that the distinctive feature of activity is its impersonal character, in the sense that it does not depend on who is performing.

At the same time, we should consider that behavior and activity are inseparable, in the same way the conscious and unconscious are in the course of constantly changing interactions of the individual with the outside world, ensuring the continuity of mental activity. In any psychic phenomenon of the conscious person there is nothing that is fully conscious or completely unconscious (Brushlinsky, 1994). Thus we need not fall victim of a false dichotomy between behavior and activity.

The integrative image of the world determines the personal choice of any stereotypes of mental activity. At the same time, the stability of the image of the world and its personal determination are considerably conditioned by the fact that "our emotions, affects, and aspirations exist in us persistently only because during certain phases of their existence do they act as systems of unconscious psychological attitudes, thereby ensuring the unity of the personality of the subject and the consistency of his or her behavior." (Bassin, 1985, p. 445).

In this regard, it is purposeful to study the behavioral stereotypes of young people today, for they are an unconscious means of interpreting events in accordance with individual socio-cultural experiences and covering all kinds of physical and mental experience. Such a cultural scheme of the individual in the context of the larger society is reasonably taken into account when organizing educational experiences.

An axiomatic feature of the educational space in the emergent information society is that the amount of information accumulated by mankind globally exceeds the amount of knowledge that can be learned by an individual. The modern education system seems focused on distilling and extracting the core of the available information which must be learned. But with the sheer volume of new knowledge, the problem is practically insoluble, especially for the Humanities, where the cumulative effect does not reduce the role of the earlier cultural layer while at the same time placing emphasis on studying the "archive of information." Even so its different clustering and systematization does not necessarily make the graduate of the university ready for professional activity. To purposefully address and solve this problem, certainly one beyond the scope of this essay, can help us to address the development of all types of individual mental activity, that is, not only in the sphere of rational consciousness, but also the unconscious one.

\section{References}

Bandura, A., \& National Inst. of Mental Health (1986). Prentice-Hall series in social learning theory. Social foundations of thought and action: A social cognitive theory. Englewood Cliffs, NJ: PrenticeHall.

Berulava, G. A. (2008). Psychology in practice. Seattle, WA: Seattle Pacific University.

Berulava, G. A. (2001). Personality style: Theory and practice. M: Russian Pedagogical Society.

Bodenhausen, G.V., \& Lichtenstein, M. (1987). Social stereotypes and information-processing strategies: The impact of task complexity. Journal of Personality and Social Psychology, 52-1987, pp. 871-880. 
Бассин, Ф.В. [Bassin, F.V.] (1985). О некоторых современных тенденциях развития теории бессознательного: установка и значимость. [On some of the current trends in the development of the theory of the unconscious: setting and significance.] Tbilisi: Metsniereba, 1985, Vol. 4.

Берулава, Г.A. [Berulava, G.A.] (2009). Методология современной психологии. [Methodology of Modern Psychology] Moscow: Moscow Psychological Social University.

Берулава, Г.A. [Berulava, G.A.] (2001). Стиль индивидуальности: теория и практика. [Style of individuality: theory and practice.] Moscow: Russian Pedagogical Society.

Берулава, Г.А. [Berulava, G.A.] (Chief ed.) (2010a). Роль стереотипов психической активности в развитии личности. [The role of stereotypes of mental activity in the development of personality] (Articles: G.A. Berulava, M.M. Berulava, Z.S. Botasheva, O.V. Nepsha, E.M. Sagilian, N.V. Splavskaya ) Moscow: Gumanitarnaya nauka.

Берулава, Г.А. [Berulava, G.A.] (2003). Методологические основы деятельности практического психолога. [Methodological basis of the practical psychologist.] Moscow: Vysshaya shkola.

Берулава, Г.А. [Berulava, G.A.] (2010b). Инновационная сетевая парадигма обучения и воспитания студентов в условиях современного информационного пространства. [Innovative network paradigm of training and education of students in the conditions of modern information space.]: Гуманизация образования [Humanization of education], No. 4-2010, pp.. 8-24.

Берулава, М.H. [Berulava, M.N.] \& Берулава, Г.А. [Berulava, G.A.] (2009). Методологические основы развития личности студента в вузе [Methodological bases of the student's personality development in the university] Вестник Университета Российской академии образования [Herald of the University of the Russian Academy of Education], No. 4-2009.

Bloom, Benjamin (1986). The Hands and Feet of Genius: Automaticity. Washington, D.C.: Educational Leadership.

Брушлинский, А. В. [Brushlinskiy, A.V.] (1994). Проблемы психологии субъекта. [Problems in the Psychology of the subject.] Moscow: Institute of Psychology RAS.

Выготский, Л.С. [Vygotskiy, L.S.] (1965). Психология искусства. [Psychology of Art] Moscow: Iskusstvo. URL: http://www.gumer.info/bibliotek Buks/Psihol/Vugotsk/PsIskus Index.php

Bruner, Jerome (1996). The Culture of Education. Cambridge, MA: Harvard University Press.

Dewey, John (1907). The School and Society. Chicago: University of Chicago Press.

James, William $(1888,1914)$. Habit. New York: Henry Holt Co.

Джеймс, У. [James, W.] (1996). Теория и практика личностно-ориентированной психологии. [Theory and Practice of the Personality Psychology.] Moscow: PIK VINITI.

Фэйдимен, Д. [Fadiman, J.] (1996). Теория и практика личностно-ориентированной психологии: Методика персонального и социального роста. [Theory and practice of personality-oriented psychology: Methods of personal and social growth.] Moscow: Tri L.

Хьелле, Л., \& Зиглер Д. [Hjelle, L. \& Ziegler, D.] (1997). Теории личности. Основные положения, исследования и применение. [Theories of personality. Basic provisions, research and application.]. Saint-Petersburg: PiterPress.

Maslow, A.H. (1943) A Theory of Human Motivation. Psychological Review, 50, pp. 370-396. URL: http://dx.doi.org/10.1037/h0054346.

Parsons, T. $(1937,1968)$. The Structure of Social Action. New York: Free Press.

Rogers, C. R. (1942). Counseling and psychotherapy; newer concepts in practice. Oxford, England: Houghton Mifflin. 
Zimmerman, A. (2011). Marxism, communism and law: How Marxism led to lawlessness and genocide in the former Soviet Union. The Western Australian Jurist 1(2), pp. 1-60.

\section{About the Authors}

Dr. Galina Alekseevna Berulava: Professor of Psychological Sciences, Full member of the Russian Academy of Education, Rector of the International Innovative University, Sochi (Russia). E-mail: naukabga@mail.ru.

Dr. Mikhail Nikolaevich Berulava: Professor of Pedagogical Sciences, Full member of the Russian Academy of Education, President of the Moscow Innovative University, Moscow (Russia). E-mail: naukabga@mail.ru. 